\title{
A 60-Year Meta-Analysis of Tick Paralysis in the United States: A Predictable, Preventable, and Often Misdiagnosed Poisoning
}

\author{
James Henry Diaz
}

Published online: 26 February 2010

(C) American College of Medical Toxicology 2010

\begin{abstract}
Tick paralysis (TP) is a neurotoxic poisoning primarily afflicting young girls in endemic regions. Recent case series of TP have described increasing misdiagnoses of $\mathrm{TP}$ as the Guillain-Barré syndrome (GBS). A meta-analysis of the scientific literature was conducted using Internet search engines to assess the evolving epidemiology of TP. Fifty well-documented cases of TP were analyzed over the period 1946-2006. Cases were stratified by demographics, clinical manifestations, and outcomes. Misdiagnoses were subjected to Yates-corrected chi-square analyses to detect statistically significant differences in proportions of misdiagnoses between earlier and later reporting periods. TP occurred seasonally and sporadically in individuals and in clusters of children and adults of both sexes in urban and rural locations. The case fatality rate (CFR) for TP was $6.0 \%$ over 60 years. The proportion of misdiagnoses of TP as GBS was significantly greater $\left(\chi^{2}=7.850, P=0.005\right)$ in more recently collected series of TP cases, 1992-2006, than the proportion of misdiagnoses in earlier series, 1946-1996. TP was a potentially lethal poisoning that occurred in children and adults in a seasonally and regionally predictable fashion. TP was increasingly misdiagnosed as GBS during more recent reporting periods. Such misdiagnoses often directed unnecessary therapies such as central venous plasmapheresis with intravenous immunoglobulin $G$, delayed correct diagnosis, and tick removal, and could have increased CFRs. TP should be added to and quickly excluded from the differential diagnoses of acute ataxia and ascending flaccid paralysis, especially in children living in TP-endemic regions of the USA.
\end{abstract}

J. H. Diaz $(\bowtie)$

LSU School of Public Health,

New Orleans, LA, USA

e-mail: jdiaz@1suhsc.edu
Keywords Arthropods, ticks · Ticks, tick paralysis · Paralysis, tick, neuromuscular, ascending · Poisoning, biological, neurotoxic

\section{Introduction}

Tick paralysis (TP) is an ascending neuromuscular paralysis with sensory sparing caused by salivary neurotoxins secreted by gravid hard ticks (Acari: Ixodidae) while blood-feeding. Although reported worldwide since the early twentieth century and transmitted by over 40 tick species, TP usually occurs in the same regions of North America and Australia during predictable spring-summer seasons [1-9]. North American TP is most commonly transmitted by Dermacentor andersoni, the Rocky Mountain wood tick, in the US Pacific Northwest, US West, and Southwestern Canada (British Columbia, Alberta; Fig. 1). In the Southeast USA, TP is usually transmitted by Dermacentor variabilis, the American dog tick (Fig. 2) [1-9]. In Eastern Australia, TP is usually transmitted by Ixodes holocyclus, the marsupial tick [10]. Most cases of TP in the USA have occurred sporadically in rural locations in girls younger than 8 years of age with long hair and felt to be predisposed to unnoticed tick blood-feeding on the head or scalp [1-9, $11,12]$.

To date, the only systematic review of TP in the USA was reported from the State of Washington in 1999 [1]. Since then, TP has been reported throughout the USA in more adults, in ectopic tick attachment sites, in urban locations, and in clusters of both adult and pediatric cases in close regional proximities [2-8]. In addition, more recent US case series of TP have described increasing misdiagnoses of TP in children as the Guillain-Barré syndrome (GBS) with critical delays in establishing correct diagnoses 


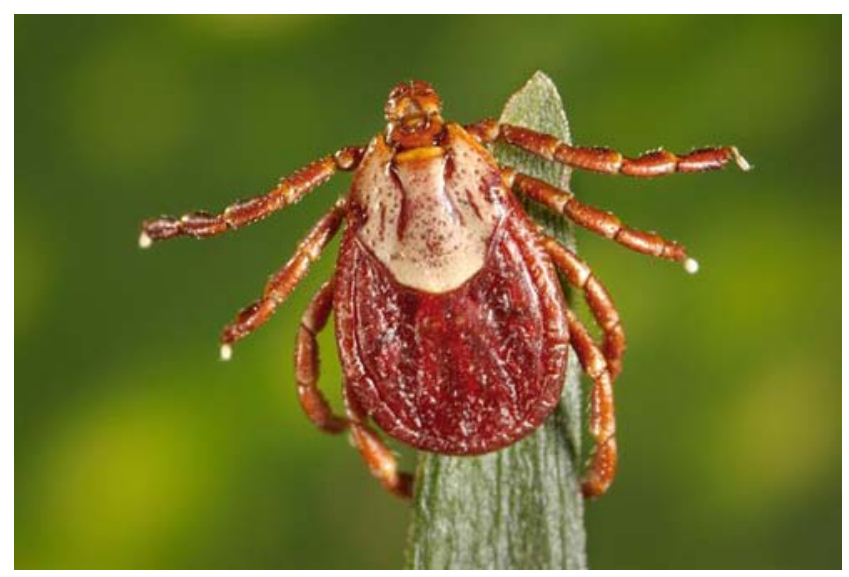

Fig. 1 A "questing" female Rocky mountain wood tick, Dermacentor andersoni, a primary vector of tick paralysis in the US Pacific Northwest and a vector of Rocky Mountain Spotted Fever (RMSF) throughout the US West. Source: US Centers for Disease Control and Prevention (CDC), Atlanta, GA, USA. CDC Public Health Image Library (PHIL). PHIL ID \#10865. No copyright permission required

and directing proper therapies $[2,12]$. Some misguided and potentially complicated therapies in these cases have included establishing central venous circulatory access, performing plasmapheresis, and administering intravenous immunoglobulin G (IVIG) [2, 7].

In light of new epidemiological and clinical data on TP in the USA since 1999, the objectives of this meta-analysis of TP in the USA will be (1) to collectively analyze similar well-documented cases of TP in children and adults throughout the USA over the 60-year period, 1946-2006; (2) to describe the evolving epidemiology of and an

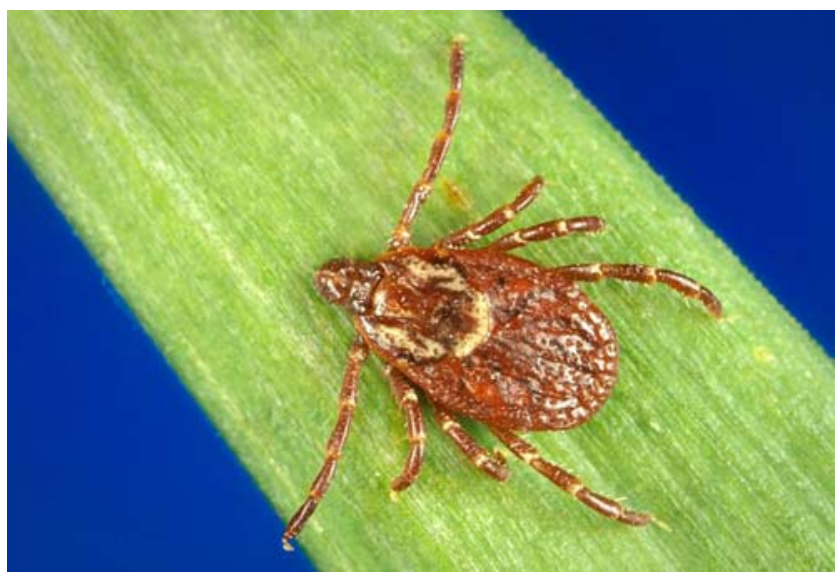

Fig. 2 A "questing" female American dog tick, Dermacentor variabilis, a vector of tick paralysis in the Southeastern USA and a secondary vector of Rocky Mountain Spotted Fever (RMSF) in addition to the Rocky Mountain wood tick, Dermacentor andersoni, in the US West. Source: US Centers for Disease Control and Prevention (CDC), Atlanta, GA, USA. CDC Public Health Image Library (PHIL). PHIL ID \#170. No copyright permission required expanded differential diagnosis for TP in the USA today; (3) to curtail the increasing misdiagnoses of TP as GBS and other acute motor polyneuropathies; (4) to avoid unnecessary therapies that could further delay or complicate the management of TP; and (5) to direct the appropriate therapy for TP by prompt, proper tick removal.

\section{Materials and Methods}

In order to assess the evolving epidemiology and expanding differential diagnosis of TP in the USA, a descriptive review and analysis of the scientific literature on TP in the USA was conducted. A literature search using the MESH term "tick paralysis" was used to select data sources describing TP by the National Library of Medicine (NLM) MEDLINE search engine, 1966-2008, and by the NLM OLD MEDLINE search engine for articles published prior to 1966. In addition, Google Scholar ${ }^{\circledR}$, Google ${ }^{\circledR}$, and library hand literature searches were conducted. Data sources included case reports, case series, observational studies, and longitudinal studies, including a summary series of TP cases in the State of Washington during the period 1946-1996 [1]. A total of nine published scientific articles contributed 50 well-documented cases of TP to the meta-analysis, which spanned a 60-year study period, 1946-2006 [1-9]. TP cases were then stratified by state distributions, regional reporting periods, seasonalities, age and sex predilections, age ranges, and specific tick attachment sites. Tick attachment sites were further stratified by location as behind the ears, on other locations on the scalp or head, on the neck, groin, or back. Case characteristics were analyzed non-parametrically as means, ranges, proportions (\%), and age and sex ratios.

Following the descriptive analysis of the evolving epidemiology of TP in the USA, a collective analysis of case-patient outcomes was conducted over the study period using similar non-parametric methodologies. Clinical case outcomes were stratified into mean incubation periods (defined as time periods from initial onset of prodromes to neurotoxic manifestations), misdiagnoses as GBS and other acute motor polyneuropathies, need for mechanical ventilation (\%), mean times to correct diagnoses, mean times to full neurological recoveries, case fatality rates (\%), and causative tick species. Misdiagnoses were defined as cases initially diagnosed as ascending neuromuscular paralysis without recognition of tick attachment followed by later discovery of tick attachment and corrected diagnosis as TP. Misdiagnoses were subsequently stratified by neurological diagnoses as either GBS $(n=9)$ or other acute motor polyneuropathies $(n=2)$. Outcomes were reported as means, ranges, rates, ratios, and proportions (\%). 
The proportions of total misdiagnoses and misdiagnoses as GBS were then subjected to Yates-corrected chi-square $\left(\chi^{2}\right)$ analyses to detect statistically significant differences in the proportions of misdiagnoses between the WA state series of TP cases (1946-1996) and the more recent collective series from other US states (1992-2006). Statistical significance was indicated by $P$ values of less than or equal to 0.05 . Power analyses at the significance level $(\alpha)$ of 0.05 in a sample size of 50 cases was conducted for each proportional comparison to determine the ability of the chi squares to find statistically significant differences if present. Since this investigation was a meta-analysis of previously published case reports and case series, Institutional Review Board approval was not required.

\section{Results}

The collective patient characteristics of 50 well-documented cases of TP in the USA reported during the study period 1946-2006 are displayed in Table 1. The collective patient outcomes of the same 50 cases of TP in the USA reported during the same period are displayed in Table 2. In comparison to the only other summary investigation of TP which was conducted in the State of Washington (19461996) and reported in 1999, some case-patient characteristics and health outcomes remained the same and others differed substantially.

The demographic characteristics that remained the same included the following: (1) Although TP has been reported throughout the USA, it remained a highly predictable, regional disease that occurred in specific geographic regions including the US Pacific Northwest (WA), the West (CA, $\mathrm{CO}$ ), and the Southeast (GA, MS, NC, SC, VA). Very few cases $(n=1)$ occurred outside of the recurring geographic distribution range of TP during the study period. (2) TP also remained a highly predictable seasonal disease and occurred in endemic regions during the spring and summer seasons, specifically March through July, when ticks were actively mating, breeding, and blood-feeding. (3) TP remained more common in females of all ages $(80 \%$ of cases, female/male ratio 4.0:1.0), and particularly in girls younger than 8 years of age $(68 \%$ of all cases, ratio of females under age 8 years to males under 8 years $=4.9: 1.0)$. (4) Tick attachment sites on the head and scalp continued to predominate over all other attachment sites, represented $48 \%$ of reported tick attachment sites (ratio=2.1:1.0), and could be further stratified as behind the ears $(20 \%)$ or attached to other sites on the head or scalp $(28 \%)$. (5) Lastly, D. andersoni, the Rocky Mountain wood tick, was the only TP vector in the Western USA (CA, CO, WA), when reported; and D. variabilis, the American dog tick, was the only TP vector from the Southeast USA (GA, NC), when reported.
The demographic characteristics that differed over the study period included the following: (1) Although TP occurred rarely in adults as compared to children, especially children younger than age 8 years, tick attachment sites in adults were often in ectopic locations, such as the back and groin $(n=4)$. (2) Although the neck remained a less frequent tick attachment site than the head or scalp in children $(n=$ $4)$, it was reported in both children and adults $(n=4)$, in keeping with the adult propensity to have ticks attach and blood-feed in locations other than the head and scalp $(n=5)$.

The case-patient health outcomes that remained the same included the following: (1) Following an unknown initial period of tick attachment for blood-feeding and secretion of paralytic neurotoxin (presumed to be 4-7 days with a mean of 5 days), a common non-specific, influenzalike prodrome with malaise and weakness occurred in most cases, and allowed an incubation period from non-specific prodrome onset to paralysis to be described with a mean of 1.4 days (range $=1-10$ days) $[1,3,6]$. (2) When properly diagnosed and treated by prompt tick removal, the time to full neurological recovery remained short with a mean of 1.5 days (range $=1-2.5$ days) following tick removal. (3) When properly diagnosed and treated by prompt tick removal, TP remained a rarely fatal poisoning with an occasional need for short-term mechanical ventilation. Five patients $(10 \%)$ required short-term mechanical ventilation; two patients from the older case series and three patients from the recent case series.

Two deaths were described in the 1940s, when mechanical ventilation for respiratory paralysis was not uniformly available [1]. Another death occurred in 1979 [5]. The collective case fatality rate (CFR) over the study period was $6.0 \%(n=3)$. In comparison, Rose reported a CFR of $11.7 \%$ in a longitudinal analysis of 332 cases of TP in Canada in 1954, prior to the widespread availability of short-term mechanical ventilation [13].

The case-patient outcomes that differed substantially between the prior summary of TP cases in Washington state in 1999 [1] and this investigation included the following: (1) TP was more frequently misdiagnosed as GBS $(n=9)$ and other acute, ascending motor neuropathies $(n=2)$. (2) Preparations for invasive intravenous therapy for GBS were initiated in four patients before tick attachment sites were discovered. Three patients received IVIG therapy [2]. In another case, a scalp-attached tick was discovered during the placement of a central venous catheter for plasmapheresis with IVIG [7].

Lastly, the proportions of total misdiagnoses of TP $\left(\chi^{2}=\right.$ 12.842, $P=0.000)$ and misdiagnoses of TP as $\operatorname{GBS}\left(\chi^{2}=\right.$ 7.850, $P=0.005)$ were significantly greater in the more recent collective series of TP cases from the USA excluding Washington state (1992-2006) than the proportions of total misdiagnoses and misdiagnoses as GBS in the earlier 
Table 1 Patient characteristics: 50 cases of documented tick paralysis in the USA, 1946-2006

\begin{tabular}{|c|c|c|c|c|c|c|c|c|c|c|c|c|c|c|}
\hline $\begin{array}{l}\text { Cases/ } \\
\text { state } \\
\text { (Ref. \#) }\end{array}$ & $\begin{array}{l}\text { US } \\
\text { state }\end{array}$ & Period & Season & $\# \mathrm{~F}$ & $\# \mathrm{M}$ & $\begin{array}{l}\text { Age } \\
(\mu)\end{array}$ & $\begin{array}{l}\text { Age } \\
(R)\end{array}$ & $\begin{array}{l}\mathrm{F} \leq 8 \\
\text { years }\end{array}$ & $\begin{array}{l}\mathrm{M} \leq 8 \\
\text { years }\end{array}$ & $\begin{array}{l}\text { Behind } \\
\text { ears }\end{array}$ & $\begin{array}{l}\text { Head } \\
\text { and } \\
\text { scalp }\end{array}$ & Neck & Groin & Back \\
\hline $33^{\mathrm{a}}(1)$ & WA & $\begin{array}{r}1946- \\
1996\end{array}$ & $\begin{array}{c}\text { March- } \\
\text { June }\end{array}$ & 25 & 8 & 12.8 & $\begin{array}{c}1- \\
82\end{array}$ & 21 & 6 & 8 & 7 & 3 & $\begin{array}{l}2 \\
\text { (adults) }\end{array}$ & 0 \\
\hline $6(2)$ & MS & $\begin{array}{r}1992- \\
1997\end{array}$ & - & 5 & 1 & 4.3 & $3-5$ & 5 & 1 & 0 & 1 & 0 & 0 & 0 \\
\hline $4(3)$ & $\mathrm{CO}$ & 2006 & $\begin{array}{l}\text { May } 26- \\
31,2006\end{array}$ & 3 & 1 & 57 & $\begin{array}{l}6- \\
83\end{array}$ & 1 & 0 & 0 & 1 & 1 & 0 & $\begin{array}{l}2 \\
\text { (adults) }\end{array}$ \\
\hline $2(4)$ & $\mathrm{SC}$ & 2002 & May-July & 2 & 0 & 6 & $5-7$ & 2 & 0 & 0 & 2 & 0 & 0 & 0 \\
\hline $1(5)$ & VA & 1979 & - & 1 & 0 & 1.6 & - & 1 & 0 & 1 & 0 & 0 & 0 & 0 \\
\hline $1(6)$ & NY & 1998 & - & 1 & 0 & 2 & - & 1 & 0 & 0 & 0 & 0 & 0 & 0 \\
\hline $1(7)$ & GA & 1999 & - & 1 & 0 & 1 & - & 1 & 0 & 0 & 1 & 0 & 0 & 0 \\
\hline $1(8)$ & $\mathrm{CA}^{\mathrm{b}}$ & 2003 & - & 1 & 0 & 1.5 & - & 1 & 0 & 0 & 1 & 0 & 0 & 0 \\
\hline $1(9)$ & $\mathrm{NC}$ & 2004 & June & 1 & 0 & 5 & - & 1 & 0 & 0 & 1 & 0 & 0 & 0 \\
\hline Totals 50 & - & $\begin{array}{c}60 \text { years } \\
1946- \\
2006\end{array}$ & $\begin{array}{l}5 \text { months } \\
\text { March- } \\
\text { July }\end{array}$ & 40 & 10 & 14.2 & & 34 & 7 & 10 & 14 & 4 & 2 & 2 \\
\hline $\begin{array}{l}\text { Percent } \\
\text { and } \\
\text { ratios }\end{array}$ & - & - & - & $\begin{array}{l}80 \% \\
4: 1\end{array}$ & $20 \%$ & - & - & $\begin{array}{l}68 \% \\
4.9: 1\end{array}$ & $14 \%$ & $20 \%$ & $28 \%$ & $8 \%$ & $4 \%$ & $4 \%$ \\
\hline
\end{tabular}

$F$ female, $M$ male, $\mu$ sample mean, $R$ range, - not reported

${ }^{\mathrm{a}}$ Two cases reported out-of-state travel: British Columbia, Montana [1]

${ }^{\mathrm{b}}$ One case reported out-of-state travel to a dude ranch in Montana [8]

Table 2 Patient outcomes: 50 cases of documented tick paralysis in the USA, 1946-2006

\begin{tabular}{|c|c|c|c|c|c|c|c|c|}
\hline $\begin{array}{l}\text { Cases per } \\
\text { state, US state } \\
\text { (Ref. \#) }\end{array}$ & $\begin{array}{l}\text { Incubation } \\
\text { period } \\
\text { (days), } \\
\text { range }\end{array}$ & $\begin{array}{l}\text { Misdiagnosis } \\
\text { (specific } \\
\text { misdiagnosis) }\end{array}$ & $\begin{array}{l}\text { Time to } \\
\text { correct } \\
\text { diagnosis } \\
\text { (days) }\end{array}$ & $\begin{array}{l}\text { Mechanical } \\
\text { ventilation } \\
\text { (n) }\end{array}$ & $\begin{array}{l}\text { Recovery } \\
\text { time } \\
\text { (days) }\end{array}$ & Deaths (CFR) & $\begin{array}{l}\text { Tick id: } \\
D . \\
\text { andersoni }\end{array}$ & $\begin{array}{l}\text { Tick id: } \\
D . \\
\text { variabilis }\end{array}$ \\
\hline 33 WA (1) & $1(1-10)$ & 2 (GBS) & 3 & 2 & - & $\begin{array}{l}2 \text { deaths; } 1 \text { in } 1946, \\
1 \\
\text { in } 1947(6 \% \text { CFR })\end{array}$ & 14 & - \\
\hline $6 \mathrm{MS}(2)$ & 2 & 3 (GBS) & 2 & 1 & 1.5 & 0 & - & - \\
\hline $4 \mathrm{CO}(3)$ & 1.75 & $\begin{array}{l}2(\mathrm{GBS}=1 ; \text { chronic } \\
\text { polyneuropathy }= \\
\text { 1) }\end{array}$ & 1.5 & 1 & 2.5 & 0 & 1 & - \\
\hline $2 \mathrm{SC}(4)$ & 1 & 0 & 0.75 & 0 & 1 & 0 & - & - \\
\hline $1 \mathrm{VA}(5)$ & - & 1 (GBS) & - & 1 & - & 1 (1979) & - & - \\
\hline $1 \mathrm{NY}(6)$ & 1 & 1 (GBS) & 2 & 0 & 1 & 0 & - & - \\
\hline 1 GA (7) & 1 & 1 (GBS) & 3 & 0 & 1 & 0 & - & 1 \\
\hline $1 \mathrm{CA}(8)$ & 3 & 0 & 1 & 0 & 2 & 0 & 1 & - \\
\hline $1(9) \mathrm{NC}$ & 1 & $\begin{array}{l}1 \text { (post-infectious } \\
\text { polyneuritis) }\end{array}$ & 4 & 0 & 1 & 0 & 0 & 1 \\
\hline Totals 49 & NA & 11 & NA & 5 & NA & 3 deaths & 16 & 2 \\
\hline $\begin{array}{l}\text { Mean times } \\
\text { (range or } \\
\% \text { ) }\end{array}$ & $1.4(1-10)$ & $\begin{array}{l}22 \% \text { of cases were } \\
\text { misdiagnosed }\end{array}$ & $\begin{array}{l}2.16 \\
(0.75- \\
4)\end{array}$ & $10 \%$ & $\begin{array}{l}1.43 \\
(1-2.5)\end{array}$ & $6 \%$ & $32 \%$ & $4 \%$ \\
\hline
\end{tabular}

CFR case fatality rate, GBS Guillain-Barré syndrome, id identification, $N A$ not applicable 
Table 3 Proportional differences in total misdiagnoses of tick paralysis and in misdiagnoses of tick paralysis as the Guillain-Barré syndrome, Washington state series (1946-1996) vs. more recent state series (1992-2006)

\begin{tabular}{llll}
\hline Collective tick paralysis (TP) series, USA, 1946-2006 [References] & $\begin{array}{l}\text { Total TP cases, } \\
1946-2006\end{array}$ & $\begin{array}{l}\text { Total misdiagnoses } \\
\text { of TP }\end{array}$ & $\begin{array}{l}\text { Total misdiagnoses of TP } \\
\text { as the GBS }\end{array}$ \\
\hline Washington state series, 1946-1996 [1] & 33 & 2 & 2 \\
Other state series, 1992-2006 [2-8] & 17 & 9 & 7 \\
Chi-square $\left(\chi^{2)}\right.$ values & NA & 12.842 & 7.850 \\
$P$ values & NA & $0.000^{*}$ & $0.005^{*}$ \\
Power analyses of the $\chi^{2}$ s at $\alpha=0.05$ and $N=50$ & 0.989 & 0.943 \\
\hline
\end{tabular}

$* P \leq 0.05$, statistically significant difference

$T P$ tick paralysis, GBS Guillain-Barré syndrome

Washington state series (1946-1996; Table 3). A power analysis of the chi squares to determine statistically significant differences in a sample size of 50 cases at a significance level of 0.05 demonstrated over $90 \%$ power for each proportional comparison (Table 3).

\section{Discussion}

First reported in North America and Australia in 1912, TP is a recurring neurotoxic poisoning that occurs in regional pockets worldwide with demographic and seasonal predictabilities [14, 15]. North American TP is characterized by a distinct prodrome that begins some time after a gravid ixodid tick bite and secretion of an unidentified salivary neurotoxin, and comprises two phases: (1) a non-specific prodromal phase of lethargy and weakness; and (2) a subsequent neurotoxic phase of acute ataxia (often described as an inability to sit up and walk without assistance) progressing to ascending flaccid paralysis [1-9, 12]. Unlike Australian TP, the recovery time to normal neurological function in North American TP is rapid and occurs within 1.5 days of tick removal [10].

Although many (over 40) species of ticks may cause TP worldwide, the preferred regional vectors of TP are also predictable with $D$. andersoni (the Rocky Mountain wood tick) causing most cases in Canada and the US Northwest and West, and D. variabilis (the American dog tick) causing most cases in the US South and Southeast (Figs. 1 and 2) [1-9]. Much less common vectors of TP in the USA have included Amblyomma americanum (the Lone Star tick), Amblyomma maculatum (the Gulf Coast tick), Ixodes scapularis (the Eastern black-legged or wood tick), and Ixodes pacificus (the Western black-legged or wood tick) $[1,6]$.

Although children, especially girls younger than age 8 years, are most commonly afflicted with TP, boys and adults may also be affected and may present with ticks attached at
Table 4 A comprehensive differential diagnosis of acute ataxia and acute ascending flaccid paralysis in children

\begin{tabular}{|c|c|}
\hline Acute ataxia & Acute ascending flaccid paralysis \\
\hline Tick paralysis & Tick paralysis \\
\hline $\begin{array}{l}\text { Acute cerebellitis (acute } \\
\text { cerebellar ataxia) }\end{array}$ & Guillain-Barré syndrome \\
\hline $\begin{array}{l}\text { Miller-Fisher syndrome (a case } \\
\text { definition must include the } \\
\text { triad of ataxia, areflexia, and } \\
\text { external ophthalmoplegia; } \\
\text { Miller-Fisher syndrome has } \\
\text { also been called a variant of } \\
\text { the Guillain-Barré syndrome) }\end{array}$ & Acute spinal cord lesion \\
\hline $\begin{array}{l}\text { Volatile organic solvent bagging, } \\
\text { huffing, or sniffing }\end{array}$ & Poliomyelitis \\
\hline \multirow[t]{13}{*}{ Acute alcohol intoxications } & Diphtheria \\
\hline & $\begin{array}{l}\text { Acute inflammatory } \\
\text { polyradiculopathy (post- } \\
\text { Campylobacter jejuni infection) }\end{array}$ \\
\hline & $\begin{array}{l}\text { Acute motor axonal neuropathy } \\
\text { (post-Campylobacter jejuni } \\
\text { infection) }\end{array}$ \\
\hline & $\begin{array}{l}\text { Acute intermittent porphyria with } \\
\text { polyneuropathy }\end{array}$ \\
\hline & Myasthenia gravis \\
\hline & Hyperkalemic periodic paralysis \\
\hline & Hypokalemic periodic paralysis \\
\hline & $\begin{array}{l}\text { Psychogenic (hysterical) } \\
\text { weakness (paralysis) }\end{array}$ \\
\hline & $\begin{array}{l}\text { Organophosphate insecticide- } \\
\text { induced nicotinic poisoning }\end{array}$ \\
\hline & Buckthorn poisoning \\
\hline & $\begin{array}{l}\text { Heavy metal poisonings: arsenic, } \\
\text { mercury }\end{array}$ \\
\hline & Elapid snake bites \\
\hline & $\begin{array}{l}\text { Marine neurotoxin poisonings: } \\
\text { paralytic shellfish poisoning, } \\
\text { tetrodotoxin poisoning, } \\
\text { palytoxin poisoning }\end{array}$ \\
\hline
\end{tabular}


sites other than the scalp and head [11]. In addition, TP may even occur in clusters of adult and pediatric cases within close proximities (less than $20 \mathrm{mi}$ ) as recently described in a four-case cluster in Colorado in May 2006 [3].

Today, more cases of TP in children are being misdiagnosed and treated as GBS before conducting careful body searches for ticks at preferred attachment sites. In their series of six pediatric cases of TP in Mississippi, Venkataraman and co-investigators reported that half of their patients $(n=3)$ were misdiagnosed as GBS and treated with IVIG before attached ticks were discovered, often by nurses or parents grooming the patient [2].

Table 5 The clinical differential diagnosis of tick paralysis versus neuromuscular paralysis with preserved sensorium

\begin{tabular}{|c|c|c|c|c|c|}
\hline $\begin{array}{l}\text { Presenting } \\
\text { clinical features }\end{array}$ & Tick paralysis & $\begin{array}{l}\text { Guillain- } \\
\text { Barré } \\
\text { syndrome }\end{array}$ & $\begin{array}{l}\text { Cervical } \\
\text { spinal } \\
\text { cord } \\
\text { lesion }\end{array}$ & Botulism & Poliomyelitis \\
\hline $\begin{array}{l}\text { Onset of } \\
\text { neuromuscular } \\
\text { paralysis }\end{array}$ & $\begin{array}{l}\text { Acute, rapid, } \\
\text { within } 24-48 \text { h }\end{array}$ & $\begin{array}{l}\text { Slower } \\
\text { onset, days } \\
\text { to weeks }\end{array}$ & $\begin{array}{l}\text { Abrupt to } \\
\text { gradual }\end{array}$ & $\begin{array}{l}\text { Gradual following acute } \\
\text { gastrointestinal prodrome. } \\
\text { Recent history of ingestion } \\
\text { of unpasteurized honey, home- } \\
\text { canned or pickled foods may } \\
\text { be present }\end{array}$ & $\begin{array}{l}\text { Gradual following a } \\
\text { prodrome of } \\
\text { fever, meningeal } \\
\text { signs, and } \\
\text { asymmetrical } \\
\text { weakness }\end{array}$ \\
\hline $\begin{array}{l}\text { Direction of } \\
\text { neuromuscular } \\
\text { paralysis }\end{array}$ & Ascending & Ascending & Ascending & Descending & Ascending \\
\hline Ataxia & Present & Absent & Absent & Absent & Absent \\
\hline $\begin{array}{l}\text { Deep tendon } \\
\text { reflexes }\end{array}$ & $\begin{array}{l}\text { Hyporeflexia } \\
\text { progressing to } \\
\text { areflexia }\end{array}$ & $\begin{array}{c}\text { Hyporeflexia } \\
\text { progressing } \\
\text { to areflexia }\end{array}$ & Variable & Variable & $\begin{array}{l}\text { Hyporeflexia } \\
\text { progressing to } \\
\text { areflexia }\end{array}$ \\
\hline Babinski sign & Absent & Absent & Present & Absent & Absent \\
\hline Sensory loss & None & Mild & Present & Absent & Absent \\
\hline Meningeal signs & Absent & $\begin{array}{l}\text { Rarely } \\
\text { present }\end{array}$ & Absent & Absent & Present \\
\hline $\begin{array}{l}\text { Ophthalmoplegia } \\
\text { (external and } \\
\text { internal) }\end{array}$ & Present & Absent & Absent & Often present and pathognomonic & Absent \\
\hline $\begin{array}{l}\text { Other cranial } \\
\text { nerve palsies }\end{array}$ & Present & $\begin{array}{l}\text { May be } \\
\text { present }\end{array}$ & Absent & Present & Absent \\
\hline Fever & $\begin{array}{l}\text { Low grade, } \\
\text { if present }\end{array}$ & $\begin{array}{l}\text { Rarely } \\
\text { present }\end{array}$ & Absent & Often present & Present \\
\hline Exanthem & May be present & Absent & Absent & Absent & Absent \\
\hline \multicolumn{6}{|l|}{ CSF findings } \\
\hline $\begin{array}{l}\text { Protein levels } \\
(\mathrm{mg} / \mathrm{dl})\end{array}$ & Normal & High $(\geq 40)$ & $\begin{array}{l}\text { Normal to } \\
\text { high }\end{array}$ & Normal & High $(\geq 40)$ \\
\hline $\begin{array}{l}\text { White cells per } \\
\mathrm{mm}^{3}\end{array}$ & $<10$ & $<10$ & Variable & $<10$ & $>10$ \\
\hline $\begin{array}{l}\text { Differential } \\
\text { counts }\end{array}$ & Normal & $\begin{array}{l}<10 \\
\text { mononuclear } \\
\text { cells } / \mathrm{mm}^{3}\end{array}$ & & Normal & \\
\hline $\begin{array}{l}\text { Nerve } \\
\text { conduction } \\
\text { studies }\end{array}$ & $\begin{array}{l}\downarrow \text { amplitude of compound } \\
\text { muscle action potentials } \\
\text { (CMAPs). Normal sensory } \\
\text { nerve action potentials. Normal } \\
\text { response to repetitive nerve } \\
\text { stimulation. } \downarrow \text { nerve conduction } \\
\text { velocities. Prolonged distal } \\
\text { motor nerve latencies }\end{array}$ & Similar & Similar & $\begin{array}{l}\text { Similar with a reduction in } \\
\text { CMAPs. However, with } \\
\text { exercise or following rapid, } \\
\text { repetitive stimulation, the } \\
\text { amplitude of CMAPs may be } \\
\text { further reduced }\end{array}$ & Similar \\
\hline $\begin{array}{l}\text { Time to } \\
\text { neurologic } \\
\text { recovery }\end{array}$ & Rapid, $\leq 24 \mathrm{~h}$ after tick removal & $\begin{array}{l}\text { Weeks to } \\
\text { months }\end{array}$ & Variable & Prolonged & Prolonged \\
\hline $\begin{array}{l}\text { Permanent } \\
\text { neurologic } \\
\text { deficits }\end{array}$ & None after tick removal & $\begin{array}{l}\text { Permanent } \\
\text { paresis } \\
\text { possible }\end{array}$ & $\begin{array}{l}\text { Permanent } \\
\text { paresis } \\
\text { possible }\end{array}$ & $\begin{array}{l}\text { Permanent paresis possible and } \\
\text { frequent }\end{array}$ & $\begin{array}{l}\text { Permanent paresis } \\
\text { common }\end{array}$ \\
\hline
\end{tabular}


A complete differential diagnosis of TP is extensive and may be divided into differential diagnoses of acute ataxia and acute ascending flaccid paralysis (Table 4). A bedside clinical differential diagnosis of acute ascending flaccid paralysis with a preserved sensorium is much narrower and should include TP, GBS, spinal cord tumor, botulism, and poliomyelitis (Table 5). Botulism causes a descending neuromuscular paralysis with a preserved sensorium and ophthalmoplegia, and poliomyelitis has been nearly eradicated by vaccination worldwide (Table 5). However, poliomyelitis may occur in unvaccinated patients with positive travel histories to polio-endemic regions or following vaccination with live oral polio virus vaccines, which are no longer recommended in the USA (Table 5). Since TP and GBS both have identical electrophysiological signatures on nerve conduction testing, the only way to differentiate the diseases is to find and remove an attached, blood-feeding tick and observe rapid neurological recovery (Table 5). Postmortem examinations of persons who have died suddenly of unexplained paralytic illnesses have demonstrated attached ticks on the head and neck of decedents [13].

Effective strategies for the prevention and control of TP include personal protective measures, landscape management, and wildlife management. Personal protective measures to prevent TP include wearing appropriate clothing, applying insect repellants to clothing and exposed skin, and performing regular tick checks. Wearing long pants tucked into socks, long-sleeved shirts, and light-colored clothing can aide in keeping ticks off of the skin and in making them easier to spot on clothing. Spraying and/or impregnating clothing with pyrethrin-/pyrethroid-containing insecticides (permethrin, deltamethrin, etc.) are highly effective repellant strategies against ticks and other insects. The topical application of insect repellants containing $10-50 \%$ formulations of $\mathrm{N}, \mathrm{N}$ diethyl-meta-toluamide directly on exposed skin is another effective and recommended measure while outdoors in tickinfested areas, with less concentrated formulations (10-30\%) recommended for children.

Most patients with TP do not recall painless tick bites, and attachment sites may be unseen or hidden by hair. Nevertheless, tick localization and removal as soon as possible, preferably within $24 \mathrm{~h}$, remain recommended strategies to rapidly reverse TP. Ticks should always be removed with forceps (or tweezers), not fingers (as squishing ticks can transmit several tickborne microbial diseases across dermal barriers or create infectious aerosols), and in contiguity with their feeding mouthparts, rather than burning ticks with spent matches, or painting embedded ticks with adhesives or nail polishes. Ticks should be removed with forceps or tweezers applied close to the point of skin attachment with gentle, steady traction applied to avoid decapitating the tick and leaving imbedded mouth parts with toxin-filled salivary glands. A discussion of landscape and wildlife management strategies to prevent tickborne diseases is beyond the scope of this investigation.

The strengths of this investigation included its simple design and collective descriptive and statistical analyses of well-documented published cases of TP, most of which were confirmed by state health departments and/or the US Centers for Disease Control and Prevention $(n=37)$. The major limitations of this investigation which could not be controlled included its small sample size $(N=50)$, overrepresentation of older cases from Washington state $(n=33)$, and retrospective analysis of a very rare disease. Nevertheless, the power of chi squares to determine significant proportional differences in the outcomes of 50 well-documented cases was greater than the recommended $80 \%$ and detected statistically significant differences when present. Further investigations of TP in studies with larger sample sizes are recommended. TP should be added to and excluded from the differential diagnoses of acute ataxia and ascending flaccid paralysis, especially in children living in TP-endemic regions of the USA to curtail a highly significant trend towards the misdiagnosis of TP as GBS or other acute motor polyneuropathies.

\section{References}

1. Dworkin MS, Shoemaker PC, Anderson DE Jr (1999) Tick paralysis: 33 human cases in Washington state, 1946-1996. Clin Infect Dis 29:1435-1439

2. Vedanarayanan VV, Evans OB, Subramony SH (2002) Tick paralysis in children: electrophysiology and possibility of misdiagnosis. Neurology 59:1088-1090

3. Cluster of tick paralysis - Colorado (2006) MMWR 2006;55:933935

4. Li Z, Turner RP (2004) Pediatric tick paralysis: discussion of two cases and literature review. Ped Neurol 31:304-307

5. Zanga JR (1979) Tick paralysis: another lethal tick-borne disease. Va Med 106:443-444

6. Bruno R, Scannell D (1998) Tick paralysis in a 2-year-old girl. J Emerg Nurs 24:13-15

7. Felz MW, Smith CD, Swift TR (2000) A six-year-old girl with tick paralysis. N Engl J Med 342:90-94

8. Gordon BM, Giza CG (2004) Tick paralysis presenting in an urban environment. Ped Neurol 30:122-124

9. Burke MS, Fordham LA, Hamrick HJ (2005) Ticks and tick paralysis: imaging findings on cranial MR. Ped Radiol 35:206-208

10. Grattan-Smith PJ, Morris JG, Johnston HM, Yiannikas C, Malik R, Russell R et al (1997) Clinical and neurophysiological features of tick paralysis. Brain 120:1975-1987

11. Felz MW, Durden LA (1999) Attachment sites of four tick species (Acari: Ixodidae) parasitizing humans in Georgia and South Carolina. J Med Entomol 36:361-364

12. Schaumburg HH, Herskovitz S (2000) The weak child-a cautionary tale. N Engl J Med 342:127-129

13. Rose I (1954) A review of tick paralysis. Can Med Assoc J 70:175-176

14. Todd JL (1912) Tick-bite in British Columbia. Can Med Assoc J 2:1118-1119

15. Cleland JB (1912) Injuries and diseases of man in Australia attributable to animals (except insects). Austral Med Gaz 32:295-299 